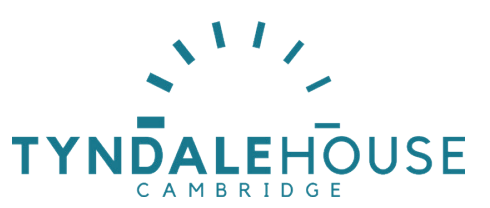

Tyndale Bulletin 72 (2021): 97-99

https://doi.org/10.53751/001c.31749

ISSN: 2752-7042 (Online)

ISSN 0082-7118 (Print)

www.tyndalebulletin.org

\author{
DISSERTATION SUMMARY
}

\title{
The Identification of New Exodus Themes in John 13-17
}

\section{Carl T. Martin}

North-West University, South Africa

carltimothymartin82@gmail.com

Within the discipline of biblical theology an interest has arisen in the presence of what has become known as New Exodus. What began as a study of New Testament references to Israel's Exodus from Egypt expanded to consider references to the Second Exodus - the promised return from exile spoken of by the prophets. New Testament writers apply references to the Exodus from Egypt and the Second Exodus return from exile in developing the theology of the New Exodus in the ministry of Jesus and the development of the church. New Exodus studies that began in the writings of the Apostle Paul were followed by those in the Letter to the Hebrews, the Synoptic Gospels, Acts, and the book of Revelation. For the Gospel of John, two studies examining New Exodus dimensions in the first ten chapters (1-4 and 5-10 respectively) have been completed. After surveying the extensive body of New Exodus literature, the present work interacts with those studies of New Exodus in the Gospel of John and carries the research forward by defining New Exodus and by examining the canonical Scriptures and selections from the intertestamental literature, culminating with a focus on John 13-17 for New Exodus themes.

After mapping out in chapter 1 the nature of the task and the procedure for the thesis as a whole, an extensive survey of research on the larger field of New Exodus studies summarises the challenge of defining terms for the study. In

1. Carl T. Martin, 'The Identification of New Exodus themes in John 13-17' (PhD diss., North-West University, 2021). Promoter: Dr S. Rochester; Co-promoter: Dr R. S. Hobyane. 
chapter 2 careful attention is given to a wide array of studies that address areas of Exodus and New Exodus studies.

Chapter 3 is devoted to Johannine studies that pertain to New Exodus. Detailed examination is undertaken of two dissertations written under the same supervisor. Both writers contend that New Exodus is 'a major interpretive key' for unlocking the New Testament. One argues for the presence of New Exodus in John 1-4. The other, without any interaction with the work on John 1-4, argues for the presence of New Exodus in John 5-10. While material from both dissertations provides helpful insight for the Gospel of John the authors did not utilise the same tools for evaluating New Exodus considerations, therefore a number of their conclusions are challenged in the present work.

Chapter 4 opens with a series of preliminary considerations. What is meant by the term New Exodus? Where did the term originate? How has its use developed? How is it identified in the larger field of research today? Though assumptions about the term are plentiful, minimal agreement about the meaning and definition of New Exodus has been attained. In this thesis, three primary categories distinguishing between Exodus, Second Exodus, and New Exodus are explored and identified. An objective framework is proposed for determining if an Exodus is present in a given passage. For this thesis, an Exodus will include all or a compelling majority of the following: (1) a reference to Egypt; (2) deliverance from slavery; (3) a reference to a wilderness experience; and (4) a safe entrance into a promised land. To provide an objective basis for locating New Exodus in a given passage, a five-part probability continuum is utilised. This is devoted to evaluating the presence of Exodus in the Old Testament, distinguishing between the accounts that anticipated the Exodus from Egypt, the Exodus event itself, and the remembrances of the deliverance from Egypt. Attention is given to the use of the term Exodus in reference to the return of the people who had been removed from Israel and endured exile under the rule of the Assyrians and later the Babylonians. Their return to the land of Judah is identified as a Second Exodus. The final section of the chapter addresses the treatment of Exodus in the Psalms.

In chapter 5, the search for Exodus, Second Exodus, and New Exodus transitions to the intertestamental literature, giving attention to apocryphal and pseudepigraphic writings of the Old Testament, the writings from Qumran, and those of Josephus and Philo. While references (allusions) to the Exodus themes are present, they are not as plentiful as some authors have claimed.

Turning to the New Testament, chapter 6 explores the potential references to Exodus, Second Exodus, and New Exodus therein (but reserving the Fourth Gospel for a separate chapter). Of interest is that the Greek term 'exodus' is only used 
three times in the New Testament. This chapter seeks to evaluate the passages wherein arguments for Exodus, Second Exodus, and/or New Exodus have been advanced. Attention is given to the Synoptic Gospels, particularly Matthew. New Exodus in Mark, which was evaluated in chapter 2 while discussing the influential work of Watts, is also considered in this chapter. Both the Gospel of Luke and his second volume of Acts are explored, before the Letters are examined for New Exodus components. Chapter 6 concludes with a search for New Exodus in Revelation.

Chapter 7, the major focus of this dissertation, examines John 13-17 in order to determine whether or not New Exodus is present. Because John 11 and 12 provide the bridge between the public ministry of Jesus and the setting of his more private ministry to the disciples in the concluding days before his passion, they too are examined for components of New Exodus. The presence of New Exodus is confirmed in these chapters in the resurrection of Lazarus, the meal at the home of Martha, Mary, and Lazarus, and the subsequent encounter with Jewish followers.

Adhering to the continuum that was applied throughout the dissertation, a careful examination of John 13-17 for the components of New Exodus provides the structure of this chapter. Because these chapters abound with compelling instruction, they have induced an abundance of studies, proposals, opinions, and evaluations. Arguments for the presence of New Exodus components in these chapters are stated. Although not all of the components are explicit, the evidence supports the possible presence of New Exodus therein.

What is the significance of this work for the reader of John's Gospel? Chapter 8 offers a series of observations, seeking to draw out from the text itself a call to the reader/hearer to profit from and respond to the message John provides about the life and ministry of Jesus. The reader is called to more than a dispassionate encounter with the text. Rather, each person is called to a personal response that affects her or his core beliefs and pattern of living in the present world as well as her or his eternal destiny. At the heart of the purpose stated in John 20:31, the Fourth Gospel appeals to all who learn of the message that 'Jesus is the Christ, the Son of God and that by believing you may have life through his name'.

Chapter 9 brings the thesis to a conclusion and chapter 10 provides the list of references cited in the dissertation. 